\title{
Effect of Coriandrum Sativum L. Leaf Extract on the Brain GABA Neurons in Mice
}

\author{
Jun Sakurai ${ }^{1}$, Nobuo Izumo ${ }^{2}$, Yasuo Watanabe ${ }^{1,2^{*}}$ \\ ${ }^{1}$ Department of Functional food, Yokohama University of Pharmacy, 601 Matano-cho, Totsuka-ku, Yokohama-shi, Kanagawa 245-0066, Japan \\ ${ }^{2}$ General Health Medical Center, Yokohama University of Pharmacy, 601 Matano-cho, Totsuka-ku, Yokohama-shi, Kanagawa 245-0066, Japan
}

\begin{abstract}
Received: 29 March, 2019; Accepted: 22 April, 2019; Published: 02 May, 2019
*Corresponding author: Dr. Yasuo Watanabe, General Health Medical Center, 601 Matano-cho, Totsuka-ku, Yokohama, Kanagawa 245-0066, Japan, E-mail: yasuwat@yok.hamayaku.ac.jp
\end{abstract}

\begin{abstract}
We have evaluated the mechanism underlying the sedative effects of coriander (Coriandrum sativum L.) using a behavioral study and real-time PCR (RT-PCR). The experimental mice were divided as: (1) control, (2) coriander leaf extract- 400 or $600 \mathrm{mg} / \mathrm{kg}$, (3) coriander seed extract- 400 or $600 \mathrm{mg} / \mathrm{kg}$, (4) main ingredients. Two hours after oral administration of coriander extracts and main ingredients, a light anesthesia $(21.6 \mathrm{mg} / \mathrm{kg})$ of pentobarbital was administered intraperitoneally (i.p.) to all mice. The time points recorded after i.p. administrations were- 1 : immediately after administration, 2 : start time of somnolence, 3: end time of somnolence. The brains were isolated from the control and coriander leaf extract groups two hours after oral administration for RT-PCR. Pentobarbital-induced somnolence duration time was compared with that of the control group. A significant difference was found in leaf and seed extract- $600 \mathrm{mg} / \mathrm{kg}$ group and linalool (main ingredient of coriander) group. RT-PCR results showed that the gene expression of $\mathrm{GABA}_{\mathrm{A}}$ receptor $\beta 1$ subunit was significantly increased and the gene expression of GABA transporter was significantly decreased in leaf extract $600 \mathrm{mg} / \mathrm{kg}$ group. This indicates that the sedative effect of coriander leaf extract is due to the hyperactivity of inhibitory neurons in the brain.
\end{abstract}

Keywords: Coriandrum sativum leaf; Coriandrum sativum seed; GABA neuron; insomnia; Righting reflex; mice

\section{Introduction}

Coriander (Coriandrum sativum L.), belonging to the family Umbelliferae/Apiaceae is an annual Mediterranean herb cultivated in many countries $[1,2]$. Coriander has been used for over 3000 years (Ebers papyrus of $1550 \mathrm{BC}$ ) as traditional medicine [3]. Also, Iranian traditional medicine has been suggested to cure medical problems such as insomnia and anxiety [4]. Coriander seed is one of the commonly used spices all over the world and was called as the "spice of happiness" in ancient Egypt $[5,6]$. Coriander leaves are used for garnishing, while the oil is used in cosmetics [3].

Amongst many ingredients of coriander, linalool is a component of unique odor, although the extent of its odor varies from one geographical location to another $[6,7]$. However, no clear differences describing the country-wise efficacy are reported, suggesting that the strength of odor and efficacy might not correlate.
Pharmacologically, the studies on the antioxidant, anticonvulsant, anxiolytic effects of coriander have been reported [8-10]. Although a report shows the sedative and hypnotic effects of coriander extracts combined with pentobarbital, there is no literature suggesting its mechanism of action [1113]. Pentobarbital is a barbiturate anesthetic that effects on the hypothalamus and enhances $\gamma$-amino butyric acid (GABA) type A $\left(\mathrm{GABA}_{A}\right)$ receptor function or GABAergic neurotransmission [14]. And pentobarbital is one of the short-acting barbiturates. Therefore, this barbiturate can be used for the experiments which find out the effects of sedation/hypnotic actions as the reference drug. To assess the sedative effect of coriander extracts, we measured somnolence time in pentobarbital induction.

In this study, we conducted a comparative search of the sedative effect of the multifunctional coriander leaf and seed extracts. Furthermore, we searched that the coriander extracts induce the sedative/hypnotic action not lonely but potentiated by GABA-acting agents. In general, the sedation is controlled by the balance of excitatory and inhibitory neuronal system in the brain. Particularly, the activation of $\mathrm{GABA}_{\mathrm{A}}$ receptor and the inhibition GABA transporter on glia cells relate to the increase of synaptic GABA activities. Furthermore, the decreases of N-methyl-Daspartate (NMDA) receptors reduce the activities of excitatory neurotransmitter such as glutamate.

In this paper, we measured the activities of $\mathrm{GABA}_{\mathrm{A}}$ receptor, GABA transporter and NMDA receptor by real-time PCR (RT-PCT). And we discussed the mechanism of sedative effect of coriander leaf extract.

\section{Materials and Methods}

In this experiment, two types of coriander extracts such as leaf and seed donated from Sami-Sabinsa Group (Bengaluru, India) were used (See the flow chart of extraction). And these extracts were administered by oral before intraperitoneal administration of pentobarbital. 


\section{Dried \& pulverized Coriander leaves and seeds}

Extraction with Aqueous Alcohol

Aqueous Alcoholic Extract

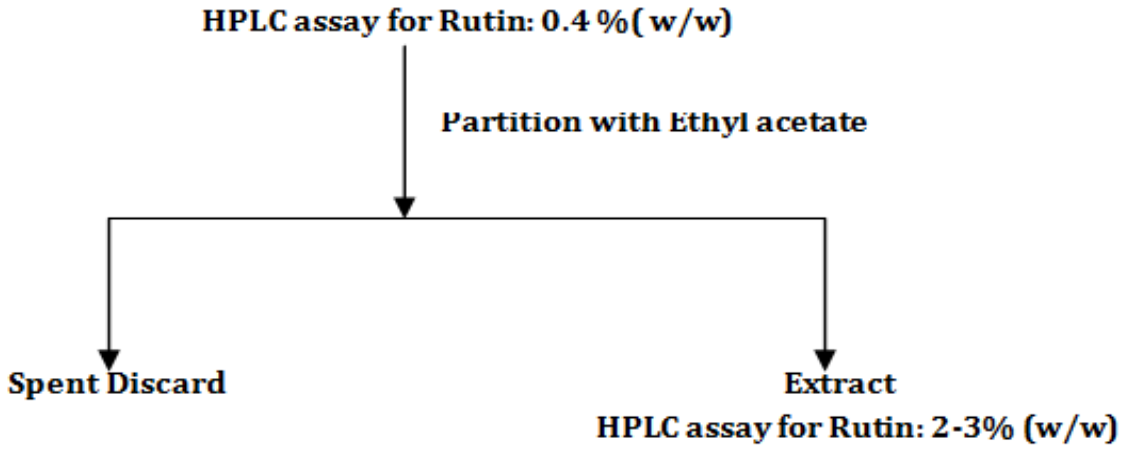

Flow Chart of Extraction: Process development for Coriandrum sativum leaves and seeds extract

\section{Animals}

Male ddY mice (Japan SLC, Inc., Shizuoka, Japan), 5-weeks old, were purchased and bred at Yokohama University of Pharmacy, Animal Experiment Research Facility. For the experiment, breeding was carried out for at least 1 week, after which the animals were used. The temperature of the breeding room was adjusted to 22 to $24{ }^{\circ} \mathrm{C}$, the humidity was 50 to $55 \%$, and the light period was set from 7 am to $7 \mathrm{pm}$. All mice were provided with normal feed (CE-2, CLEA Japan, Inc., Tokyo, Japan). This study was carried out by the permission of Yokohama University of Pharmacy experimental animal committee, keeping in consideration the welfare of laboratory animals.

\section{Procurement of Coriander Extract}

The coriander leaf and seed extracts were donated by the Sabinsa Japan Corporation.

\section{Experimental Design}

The mice were randomly divided into six groups $(n=6$ for each group):

1. Control: Water containing Polyethylene Glycol 400 (PEG, Wako Pure Chemical Industries, Ltd., Osaka, Japan);

2. Coriander leaf extract, either 400 or $600 \mathrm{mg} / \mathrm{kg}$;

3. Coriander seed extract, either 400 or $600 \mathrm{mg} / \mathrm{kg}$;

4. Main ingredient of the seed: linalool $280 \mathrm{mg} / \mathrm{kg}$ (Tokyo Chemical Industry Co., Ltd., Tokyo, Japan);

5. Main ingredient of the leaf: (E)-2-decenal $60 \mathrm{mg} / \mathrm{kg}$ (Tokyo Chemical Industry Co., Ltd., Tokyo, Japan); and
6. Main ingredient of leaf: decanal $60 \mathrm{mg} / \mathrm{kg}$ (Wako Pure Chemical Industries, Ltd., Osaka, Japan).

Water was used as a vehicle for coriander leafand seed extracts. Also, PEG containing water was used as a vehicle for linalool, (E)2-decenal, and decanal. Linalool comprises roughly $70 \%$ of the essential oil in coriander seed while (E)-2-decenal and decanal form $15 \%$ of the coriander leaf essential oil [7]. In essence, each dose constitutes $280 \mathrm{mg} / \mathrm{kg}$ linalool and $60 \mathrm{mg} / \mathrm{kg}$ (E)-2-decenal and decanal. The pentobarbital-induced somnolence time was observed for 2 hours after oral administration. Furthermore, the brain was extracted from the control group as well as the coriander leaf extract (400 and $600 \mathrm{mg} / \mathrm{kg}$ ) group 2 hours after oral administration for RT-PCR.

\section{Potentiation of Pentobarbital-Induced Somnolence Time}

Pentobarbital sodium $64.8 \mathrm{mg} / \mathrm{mL}$ (Somnopentyl ${ }^{\circledR}$, Kyoritsu Seiyaku Co., Tokyo, Japan) was diluted with saline to a dose of $21.6 \mathrm{mg} / \mathrm{kg}$. Two hours after oral administration of coriander extracts and main ingredients, $21.6 \mathrm{mg} / \mathrm{kg}$ of pentobarbital was intraperitoneally (i.p.) administered to all mice. This dose was optimized such that the untreated mice did notshow loss of righting reflex. Loss of righting reflex was defined as the ineptitude of mice to right them when positioned in a supine position. The following periods were recorded post intraperitoneal administration: 1- immediately after administration, 2- commencement time of somnolence, and 3- end time of somnolence. The time obtained by subtracting 1 from 2 for each time was taken as the pentobarbitalinduced onset time, and the time subtracting 2 from 3 was taken as the pentobarbital-induced somnolence duration time. 
Furthermore, the number of mice exhibited loss of righting reflex, and it was used as an index of pentobarbital-induced somnolence potentiation. Each mouse was experimented with individual gauges so as not to be disturbed by adjacent mice.

\section{Real-time PCR}

The brains from each of the mice were divided into seven regions (frontal cortex, occipital cortex, hippocampus, corpus striatum, cerebellum, thalamus/hypothalamus, and brainstem). To extract the RNA, homogenization was done with the addition of POLYTRON PT 1300 D (Central Scientific Trade Co. Ltd., Tokyo, Japan) with Isogen (Nippon Gene Co., Tokyo, Japan) to the brain region excised from each mouse. In the next step, chloroform (Nacalai Tesque Inc., Kyoto, Japan) was added, the samples centrifuged, and subsequently the supernatant was recovered in a new tube. Isopropanol (Nacalai Tesque Inc., Kyoto, Japan) was added to the supernatant and after another centrifugation, the precipitate was recovered, dissolved in sterilized water, and RNA concentration was quantified. Next, the RNA concentration was standardized to $50 \mathrm{ng} / \mu \mathrm{L}$ according to the Super Script VILO cDNA Synthesis kit protocol (Thermo Fisher Scientific Inc., Massachusetts, USA), and incubated at $25^{\circ} \mathrm{C}$ for $10 \mathrm{~min}, 42^{\circ} \mathrm{C}$ for $60 \mathrm{~min}$ and at $85^{\circ} \mathrm{C}$ for $5 \mathrm{~min}$ to obtain cDNA. Using a Light Cycler ${ }^{\circledR}$ 480 II (F. Hoffmann-La Roche, Ltd., Basel, Switzerland) and a primer against each template marker the cDNA was amplified by TaqMan probe method Table 1. With glyceraldehyde-3-phosphate dehydrogenase (GAPDH) as the standard, the genetic markers $\mathrm{GABA}_{\mathrm{A}}$ receptor $\alpha 1$ and $\beta 1$ subunits, GABA transporter, and NMDA receptor levels were measured.

Table 1: List of all primers for real-time PCR

\begin{tabular}{|c|c|c|c|}
\hline Gene & Universal Probe Library & Forward (Left) & Reverse (Right) \\
\hline GAPDH & $\# 9$ & AGCTTGTCATCAACGGGAAG & TTTGATGTGGGGTCTCG \\
\hline GABA $_{\mathbf{A}}$ receptor $\boldsymbol{\alpha} \mathbf{1}$ subunit & $\# 78$ & TGCTTGCAACCTGCCTTT & CTCGCTTCCCTGCTAGAACA \\
\hline GABA $_{\mathbf{A}}$ receptor $\boldsymbol{\beta} \mathbf{1}$ subunit & $\# 80$ & CCCTCTGGATGAGCAAAACT & AATTCGATGTCATCCGTGGTA \\
\hline GABA transporter & $\# 4$ & GCATCATCGTGTTCAGCTACA & GCATGTTGCCTTCGAGAGA \\
\hline NMDA receptor & $\# 8$ & TGCCAGCTATACAGCCAATCT & ACGGTGTCCACGTACTCCTC \\
\hline
\end{tabular}

\section{Statistical Analyses}

The statistical significance was assessed using one way analysis of variance (ANOVA) and subsequently, results from all data were compared with those of the control group. All values were expressed as mean $\pm \mathrm{SE}$ and $\mathrm{P}<0.05$ was considered significant. The results were analyzed using the Stat View 5.0 statistical software (SAS Institute Inc., North Carolina, USA).

\section{Results}

\section{Effect of Coriander Extract on Potentiation of Pentobarbital-Induced Somnolence Time}

Pentobarbital was i.p. administered to mice and the pentobarbital-induced somnolence onset time was compared with that of control group, where the significant difference was observed in the leaf extract $600 \mathrm{mg} / \mathrm{kg}$ group compared with control group $(\mathrm{P}<0.05)$ Figure $1 \mathrm{~A}$.

Next, the pentobarbital-inducted somnolence duration time was compared with control group. A significant difference was found in leaf extract $600 \mathrm{mg} / \mathrm{kg}$ group compared with control group $(\mathrm{P}<0.01)$. Similarly, the pentobarbital-induced somnolence duration time was significantly different $(\mathrm{P}<0.05)$ in the seed extract $600 \mathrm{mg} / \mathrm{kg}$ group compared with the control group. However, no significant differences were observed in the $400 \mathrm{mg} / \mathrm{kg}$ groups of the leaf and seed extracts Figure 1B.
In the leaf extract group, the duration time was increased by $114 \%$ and $189 \%$, respectively, compared with control group. In the seed extract group, the duration time was increased by $106 \%$ and $127 \%$, respectively, compared with control group. Mice with loss of righting reflex were $0 \%$ in control group and leaf and seed extract $400 \mathrm{mg} / \mathrm{kg}$ groups, while they were $100 \%$ in the leaf extract $600 \mathrm{mg} / \mathrm{kg}$ group, and $16.7 \%$ in seed extract $600 \mathrm{mg} / \mathrm{kg}$ group.

Effect of the Main Ingredients of Coriander on Potentiation of Pentobarbital-Induced Somnolence Time

Pentobarbital was administered to the mice intraperitoneally and the pentobarbital-induced somnolence onset time was compared with that of the control group. However, no significant difference was observed Figure 1C.

Pentobarbital-induced somnolence duration time was compared with the control group, and a major difference was observed in the linalool group $(\mathrm{P}<0.01)$. However, for the (E)2-decenal group decanal groups, no significant differences were recorded Figure 1D. 


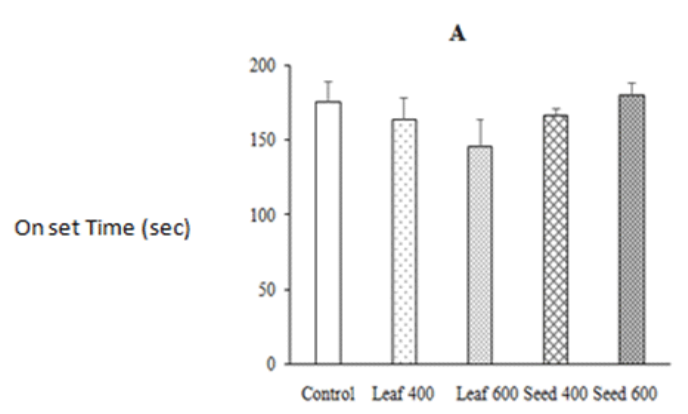

C

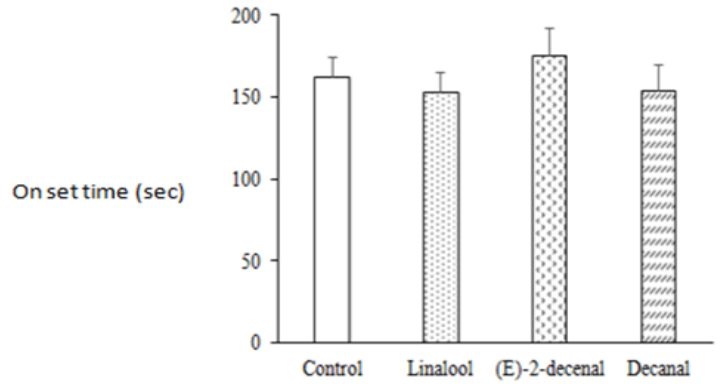

B
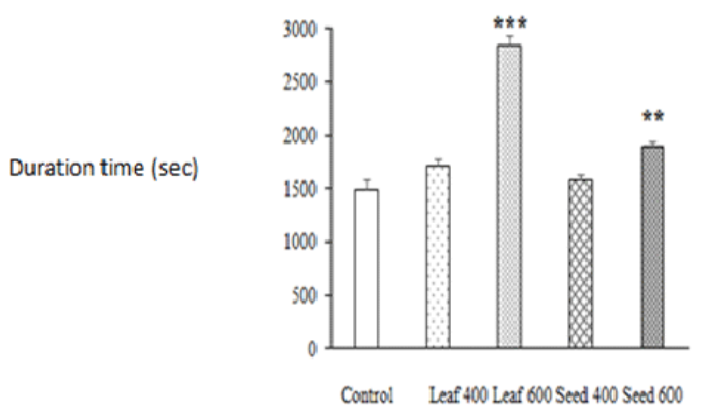

D

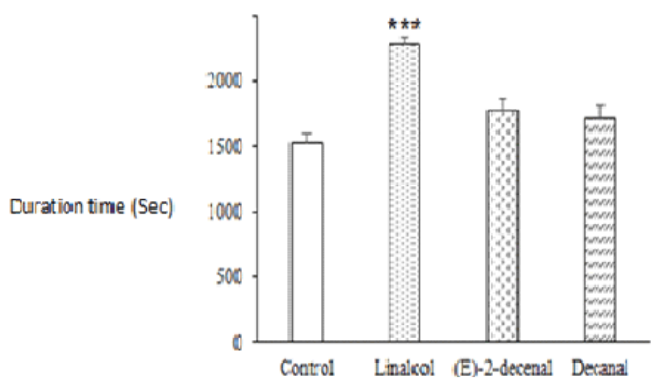

Figure 1: Effect of coriander extracts on pentobarbital-induced somnolence onset time

(A) Pentobarbital induced somnolence duration time,(B) Effect of main ingredients of coriander on pentobarbital-induced somnolence onset time

(C) Each value shows the mean \pm SE. ${ }^{* *} P<0.01,{ }^{* *} P<0.001$ compared with control group, (D) and pentobarbital-induced duration time

Linalool group, (E)-2-decenal group, and decanal group had increased duration time by $149 \%, 116 \%$ and $112 \%$, respectively, relative to the control group. Mice with loss of righting reflex were not seen in the control group and main ingredients of coriander group.

\section{Real-time PCR}

The mRNA expression of each of the genes in the excised brain region was measured by RT-PCR. The gene expressions were normalized to the expression level of the GAPDH gene and were compared to the expression level of control group. GABA receptor $\alpha 1$ subunit was compared to the control group, but no significant differences were observed in all of the seven brain regions.

$\mathrm{GABA}_{\mathrm{A}}$ receptor $\beta 1$ subunit was found to be significantly raised in the cerebellum when compared to the control group (P $<0.01$, Figure 2).

GABA transporter was significantly reduced in the brainstem with respect to the control and leaf extract $400 \mathrm{mg} / \mathrm{kg}$ groups $(\mathrm{P}<0.05)$. Moreover, in the leaf extract $600 \mathrm{mg} / \mathrm{kg}$ group, it was significantly decreased in the occipital cortex, corpus striatum, brainstem $(\mathrm{P}<0.05)$, and thalamus/hypothalamus $(\mathrm{P}<0.01$, Figure 3).
Relative to the control and leaf extract $600 \mathrm{mg} / \mathrm{kg}$ groups, NMDA receptor was significantly downregulated in the occipital cortex and thalamus/hypothalamus $(\mathrm{P}<0.05)$. This was also accompanied by a significant decrease in the corpus striatum $(\mathrm{P}<$ 0.01 , Figure 4).

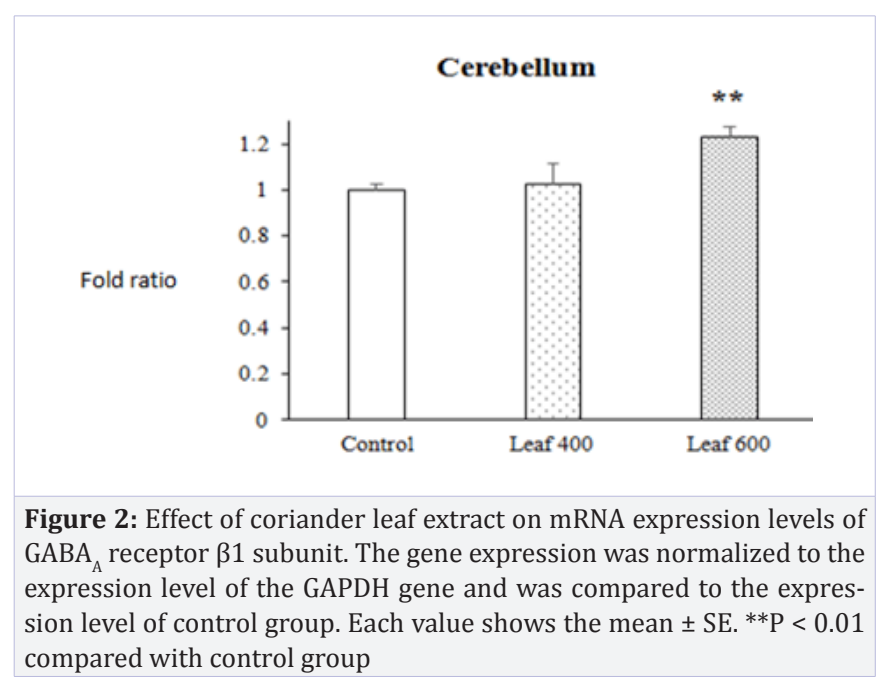



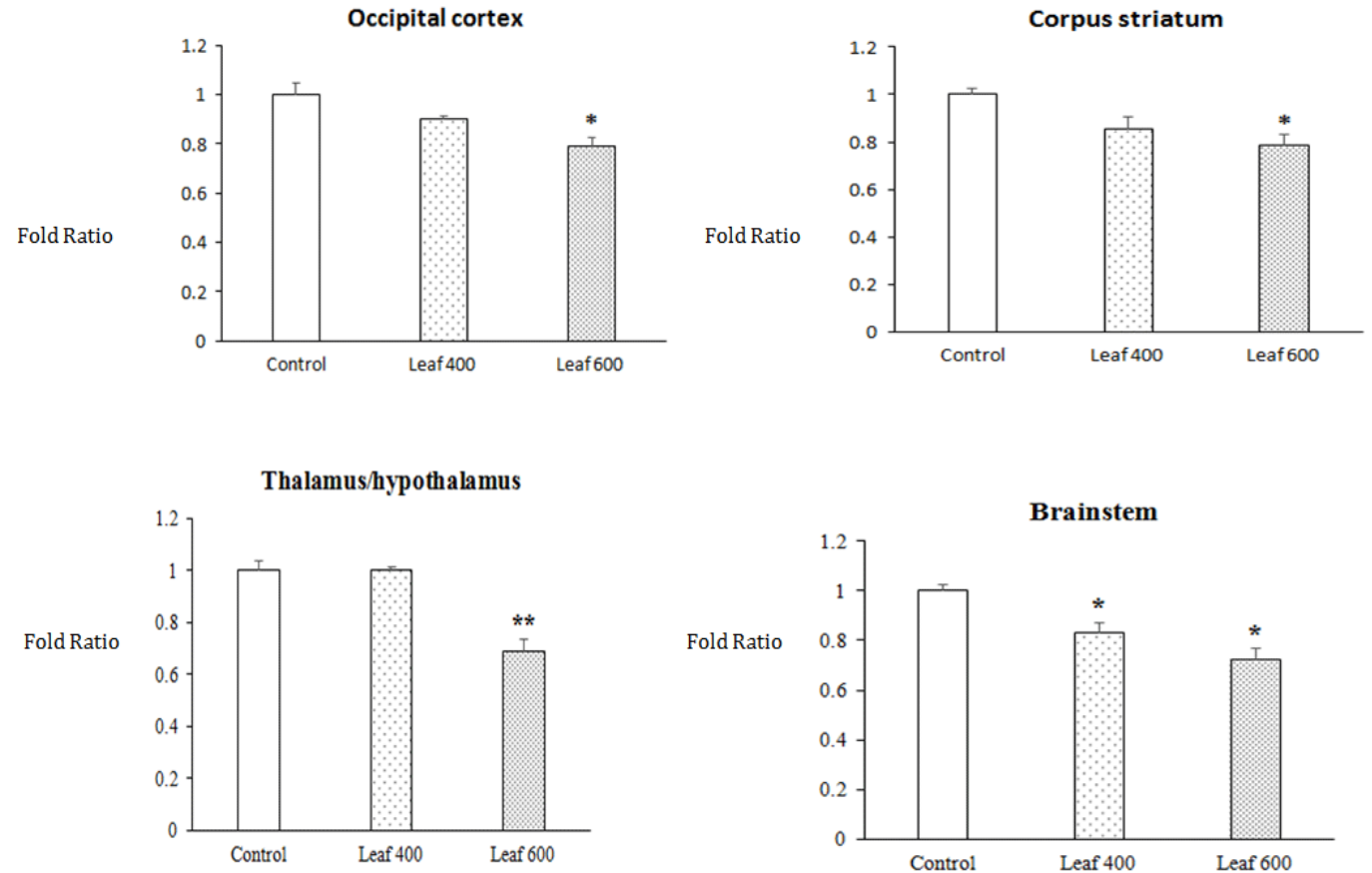

Figure 3: Effect of coriander leaf extract on mRNA expression levels of GABA transporter. The gene expression was normalized to the expression level of the GAPDH gene and was compared to the expression level of control group. Each value shows the mean $\pm \mathrm{SE} .{ }^{*} P<0.05,{ }^{* *} P<0.01$ compared with control group
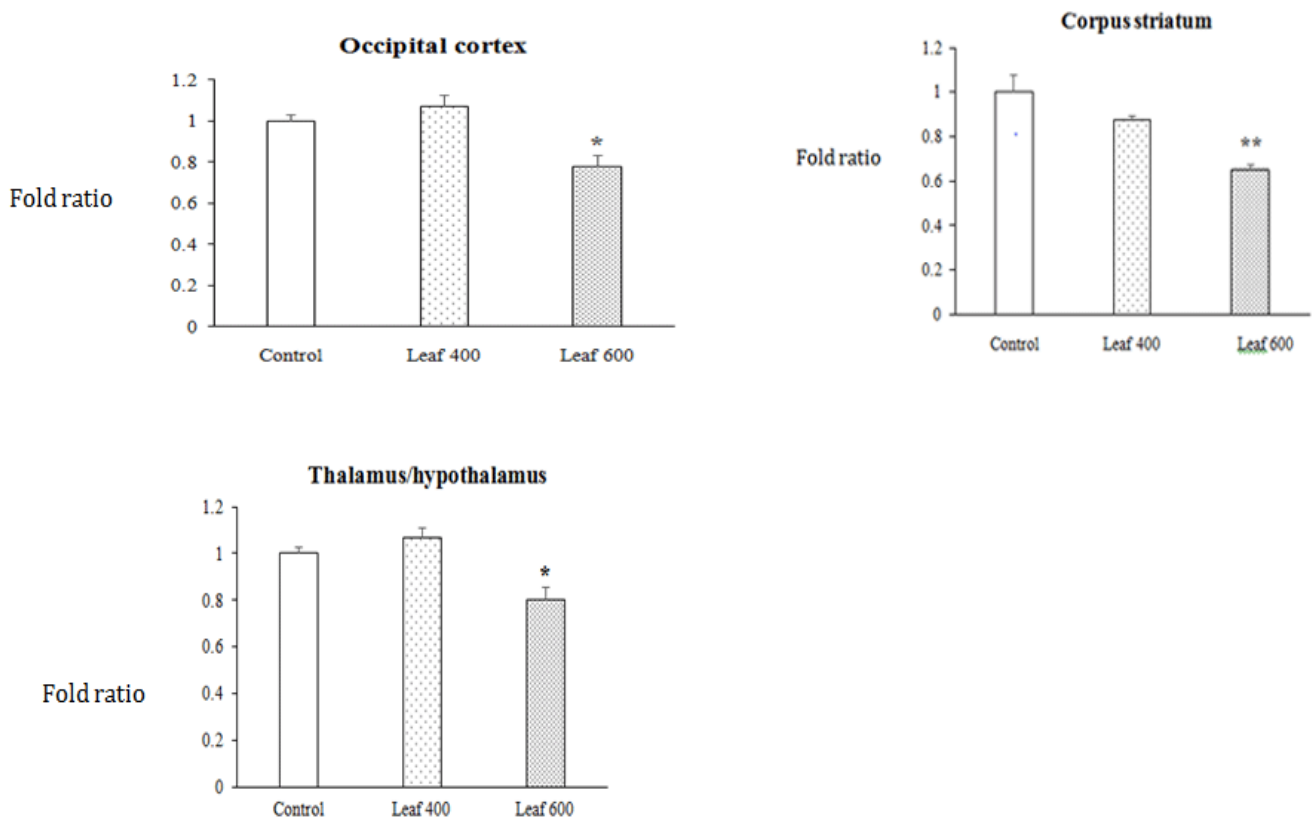

Figure 4: Effect of coriander leaf extract on mRNA expression levels of NMDA receptor. The gene expression was normalized to the expression level of the GAPDH gene and was compared to the expression level of control group. Each value shows the mean $\pm \mathrm{SE}$. ${ }^{*} \mathrm{P}<0.05$, ${ }^{* *} \mathrm{P}<0.01$ compared with control group 


\section{Discussion}

It has already been reported that extension of sleeping time induced by pentobarbital was enhanced by coriander seed extract [11-13]. This effect of coriander seed extract is due to a water-soluble monoterpene glycoside, (3S, 6E)-8-hydroxylinalool 3-0- $\beta$-D-glucopyranoside [15]. Furthermore, in the extract of the aerial parts of coriander, the potentiation of hypnotic function induced by pentobarbital has also been reported [13]. However, it has been no reports that the main ingredient of aerial parts of coriander induced such hypnotic functions. While these studies assessed the sleep time potentiation induced by pentobarbital, we investigated at lower doses of pentobarbital which does not lose righting reflex in mice. Consequently, we found out that the larger dosage of coriander leaf and seed extracts potentiated the pentobarbital-induced somnolence duration time. Our results support a previously reported study stating that the action of pentobarbital is potentiated by pretreatment of coriander extract $[11,12]$

Potentiation of the pentobarbital-induced somnolence onset and duration times were observed in the leaf extract group rather than seed extract group. Therefore, we performed RT-PCR in leaf extract group to check the GABA receptor, which is a major inhibitory neurotransmitter receptor in the brain region, GABA transporter, which aids in the removal of GABA from the synapse to surrounding astrocytes, and NMDA receptor, the excitatory neurotransmitter receptor [16-18]. As a result, there was no change in the gene expression level of $\mathrm{GABA}_{\mathrm{A}}$ receptor $\alpha 1$ subunit involved in the sedative hypnotic effect [19].

Gene expression of the $\mathrm{GABA}_{\mathrm{A}}$ receptor $\beta 1$ subunit which involved in the endogenous sleep pathway was increased by coriander leaf [20]. On the other hand, gene expressions of GABA transporter and NMDA receptor were decreased. These results indicate that the increases of GABA levels in the synaptic cleft are induced and the excitatory activity can be reduced by the administration of coriander leaf extracts.

In the main ingredient of coriander seed, linalool, exerts a sedative effect in mice [21]. Furthermore, linalool inhibits the binding of glutamic acid to the NMDA receptor in the rat cerebral cortex [22]. We studied whether the main ingredient of coriander affects the pentobarbital-induced somnolence duration. Based on our results, we suggested that linalool potentiates the pentobarbital-induced somnolence duration time over (E)-2decenal and decanal. Our results were supported by an earlier report claiming that the sedative effect is potentiated by treatment of linalool [21]. However, (E)-2-decenal and decanal which are the main leaf extract ingredients, did not significantly increase potentiation of pentobarbital-induced somnolence duration time.

This study shows that coriander leaf extract potentiates the action of low dose pentobarbital much more efficiently than the seed extract. As a central mechanism of coriander leaf extract, the potentiation of GABAergic neurons in the brain was detected. These results suggest that the sedative effect of coriander leaf extract is due to the hyperactivity of inhibitory neurons in the brain. However, the identity of the specific component of leaf extract contributing to the sedative effect remains unclear.

\section{Conclusion}

The sedative effect of coriander leaf extract is due to the hyperactivity of inhibitory neurons in the brain. However, such sedation induced by coriander leaf extract can be potentiated by GABA-acting drugs or functional materials.

\section{Authors' Contributions}

JS and NI performed most of the experiments. YW designed the experiments and gave advices during the research.

\section{Availability of Data and Materials}

The datasets used and/or analyzed during the current study are available from the corresponding author on responsible request.

\section{Ethics Approval and Consent to Participate}

NA

\section{Clinical trial registration}

NA

\section{Acknowledgement}

The authors are thankful to Mr. Yu Kuwahara, Kazuto Homma, and Masaya Miyazaki, students of Yokohama University of Pharmacy, for their helpful assistance while preparing the manuscript. And also, we appreciate Prof. Makoto Nakano and Dr. Kohsuke Hayamizu to their kind advices.

\section{Funding}

Annual Research Grant from Yokohama University of Pharmacy

\section{References}

1. Burdock GA, Carabin IG. Safety assessment of coriander (Coriandrum sativum L.) essential oil as a food ingredient. Food Chem Toxicol. 2009;47(1):22-34. doi: 10.1016/j.fct.2008.11.006

2. Mandal S, Mandal M. Coriander (Coriandrum sativum L.) essential oil: chemistry and biological activity. Asian Pacific Journal of Biomedicine. 2015;5(6):421-428.

3. Sahib NG, Anwar F, Gilani AH, Azizah AH, Hamid AA, Saari N, et al. Coriander (Coriandrum sativum L.): A Potential Source of High-Value Components for Functional Foods and Nutraceuticals- A Review. Phytother Res. 2013;27(10):1439-1456. doi: 10.1002/ptr.4897

4. Emamghoreishi M, Khasaki M, Aazam MF. Coriandrum sativum: evaluation of its anxiolytic effect in the elevated plus-maze. Journal of Ethnopharmacology. 2005;96(3):365-370.

5. Nadeen M, Anjum FM, Khan MI, Tehseen S, El-Ghorab A, Sultan JI. Nutritional and medicinal aspects of coriander (Coriandrum sativum L.) A review. British Food Journal. 2013;115(5):743-755.

6. Prachayasittikul V, Prachayasittikul S, Ruchirawat S, Prachayasittkul V. Coriander (Coriandrum sativum): A promising functional food toward 
the well-being. Food Res Int. 2018;105:305-323. doi: 10.1016/j. foodres.2017.11.019

7. Laribi B, Kouki K, M'Hanadi M, Bettaieb T. Coriander (Coriandrum sativum L.) and its bioactive constituents. Fitoterapia. 2015;103:9-26. doi: 10.1016/j.fitote.2015.03.012

8. Anaeigoudari A, Hosseini M, Karami R, Vafaee F, Mohammadpour $\mathrm{T}$, Ghorbani A, et al. The effects of different fractions of Coriandrum sativum on pentylenetetrazole-induced seizures and brain tissues oxidative damage in rats. Avicenna J Phytomed. 2016;6(2):223-235.

9. Mahendra P, Bisht S. Anti-anxiety activity of Coriandrum sativum assessed using different experimental anxiety models. Indian J Pharmacol. 2011;43(5):574-577. doi: 10.4103/0253-7613.84975

10. Wangensteen H, Samuelsen AB, Malterud KE. Antioxidant activity in extracts from coriander. Food Chemistry. 2004;88:293-297.

11. Alshahrani AM. In-vivo neurological assessment of sedative hypnotic effect of Coriandrum sativum L. seeds in mice. International journal of phytomedicine. 2016;8(1):113-116.

12. Emamghoreishi M, Heidari-Hamedani G. Sedative-Hypnotic Activity of Extracts and Essential Oil of Coriander Seeds. Iranian Journal of Medical Sciences. 2006;31(1):22-27.

13. Rakhshandeh H, Sadeghnia HR, Ghorbani A. Sleep-prolonging effect of Coriandrum sativum hydro-alcoholic extract in mice. Nat Prod Res. 2012;26(22):2095-2098. doi: 10.1080/14786419.2011.613388

14. Nelson LE, Guo TZ, Lu J, Saper CB, Franks NP, Maze M. The sedative component of anesthesia is mediated by $\mathrm{GABA}_{\mathrm{A}}$ receptors in an endogenous sleep pathway. Nature Neuroscience. 2002;5(10):979984.
15. Ishikawa T, Kondo K, Kitajima J. Water-Soluble Constituents of Coriander. Chem Pharm Bull (Tokyo). 2003;51(1):32-9.

16. Sieghart W. Structure, Pharmacology, and Function of $\mathrm{GABA}_{\mathrm{A}}$ receptor subtypes. Advances in Pharmacology. 2006; 54:231-263.

17. Madsen KK, Ebert B, Clausen RP, Krogsgaard-Larsen P, Schousboe A, White HS. Selective GABA transporter inhibitors tiagabine and EF1502 exhibit mechanistic differences in their ability to modulate the ataxia and anticonvulsant Action of the extrasynaptic GABA(A) receptor agonist gaboxadol. J Pharmacol Exp Ther. 2011;338(1):214-219. doi: 10.1124/jpet.111.179671

18. Collingridge GL, Lester RA. Excitatory Amino Acid Receptors in the Vertebrate Central Nervous System. Pharmacol Rev. 1989;41(2):143210.

19. Rudolph U, Mohler H. GABA-based therapeutic approaches: $\mathrm{GABA}_{\mathrm{A}}$ receptor subtype functions. Curr Opin Pharmacol. 2006;6(1):18-23.

20. Yanovsky Y, Schubring S, Fleisher W, Gisselmann G, Zhu XR, Lubbert $\mathrm{H}$, et al. GABA $\mathrm{A}_{\mathrm{A}}$ receptors involved in sleep and anesthesia: $\beta 1$ - versus $\beta 3$-containing assembles. Pflugers Arch. 2012;463(1):187-199. doi: 10.1007/s00424-011-0988-4

21. Linck VM, da Silva AL, Figueiro M, Piato AL, Herrmann AP, Birck FD, et al. Inhaled linalool-induced sedation in mice. Phytomedicine. 2009;16(4):303-307. doi: 10.1016/j.phymed.2008.08.001

22. Elisabetsky E, Marschner J, Souza DO. Effects of Linalool on Glutamatergic System in the Rat Cerebral Cortex. Neurochem Res. 1995;20(4):461-465. 